IZA DP No. 9995

Can Wage Subsidies Boost Employment in the Wake of an Economic Crisis? Evidence from Mexico

Miriam Bruhn

June 2016 


\title{
Can Wage Subsidies Boost Employment in the Wake of an Economic Crisis? Evidence from Mexico
}

\author{
Miriam Bruhn \\ World Bank and IZA \\ Discussion Paper No. 9995 \\ June 2016 \\ IZA \\ P.O. Box 7240 \\ 53072 Bonn \\ Germany \\ Phone: +49-228-3894-0 \\ Fax: +49-228-3894-180 \\ E-mail: iza@iza.org
}

\begin{abstract}
Any opinions expressed here are those of the author(s) and not those of IZA. Research published in this series may include views on policy, but the institute itself takes no institutional policy positions. The IZA research network is committed to the IZA Guiding Principles of Research Integrity.

The Institute for the Study of Labor (IZA) in Bonn is a local and virtual international research center and a place of communication between science, politics and business. IZA is an independent nonprofit organization supported by Deutsche Post Foundation. The center is associated with the University of Bonn and offers a stimulating research environment through its international network, workshops and conferences, data service, project support, research visits and doctoral program. IZA engages in (i) original and internationally competitive research in all fields of labor economics, (ii) development of policy concepts, and (iii) dissemination of research results and concepts to the interested public.
\end{abstract}

IZA Discussion Papers often represent preliminary work and are circulated to encourage discussion. Citation of such a paper should account for its provisional character. A revised version may be available directly from the author. 


\section{ABSTRACT}

\section{Can Wage Subsidies Boost Employment in the Wake of an Economic Crisis? Evidence from Mexico*}

The rise in unemployment during an economic crisis poses a significant concern to policy makers. This paper measures the effect of a program in Mexico that granted firms in certain industries wage subsidies if they decided to keep their workers instead of letting them go during the recent economic crisis. The analysis uses monthly administrative data on employment at the industry level, along with propensity score matching to construct groups of eligible and ineligible durable goods manufacturing industries that display statistically identical pre-program trends in employment. Difference-in-difference results show a positive but not statistically significant effect of the wage subsidies on employment during the program's eight-month duration, ranging from 5.7 to 13.2 percent in magnitude, depending on the specification. The size of the effect increases to 24 percent after the program ended and the results indicate that employment after the program recovered faster in eligible industries than in ineligible industries.

JEL Classification: J23, H32, L60

Keywords: $\quad$ wage subsidies, industrial policy, crisis mitigation, firm behavior

Corresponding author:

Miriam Bruhn

The World Bank

1818 H Street N.W.

Washington, DC 20433

USA

E-mail: mbruhn@worldbank.org

\footnotetext{
* I thank David McKenzie and Will Wiseman for valuable comments and the Mexican Social Security Institute (IMSS) for sharing their data on employment in manufacturing industries. Nathaniel Russell, Christian Salas, and Lucía Juárez provided excellent research assistance.
} 


\section{Introduction}

The rise in unemployment during an economic crisis poses a significant concern to policy makers. Moreover, layoffs could slow down the economic recovery, since re-hiring and training workers may be costly for firms. This is particularly true for workers who have acquired job-specific skills. For these workers, it may be beneficial for firms to not let them go in the first place. However, as firms face lower demand for their products, they may not have the financial means to keep paying these workers, particularly in the presence of credit constraints, which are often exacerbated during a crisis. There could thus be a case for government intervention through wage subsidies, which could limit layoffs and speed up economic recovery by eliminating search and training costs. In fact, 22 countries around the world used some form of wage subsidy program to promote employment retention during the recent economic crisis. $^{1}$

Much of the existing literature on wage subsidies focuses on subsidies for disadvantaged workers or for the unemployed (Kaldor 1936, Layard and Nickell 1980, and Phelps 1994), providing mixed evidence as to whether subsidies can improve the employment prospects of such workers (see Katz 1998 and Betcherman et al. 2004 for summaries of the literature). To my knowledge, there is, however, no empirical evidence on whether wage subsidies during an economic crisis can reduce layoffs and whether they promote economic recovery. This paper starts to fill this gap by examining a wage subsidy program that the Mexican government implemented in response to the recent economic crisis. Under this program, manufacturing firms in certain industries were eligible for receiving wage subsidies if they decided to keep their workers instead of letting them go during the period of January 2009 to August 2009.

I use monthly administrative data on employment at the industry level from the Mexican Social Security Institute (IMSS), covering nine years before and four years after program implementation, along with propensity score matching to construct groups of eligible and ineligible durable goods manufacturing industries that display statistically identical pre-program trends in employment. I then estimate difference-in-difference equations and find a positive, but not statistically significant effect of the wage subsidies on employment during the program's duration, ranging from 5.7 percent to 13.2 percent in magnitude, depending on the specification. The size of the effect is greater after the program ended: eligible industries had about 24 percent higher employment than ineligible industries, compared to the pre-program difference in employment.

I then examine the time path of the program's effect in more detail, estimating a separate effect for each year after the program (2009 to 2013) and find that the effect of the program increases over time going from about 16 percent in 2010 to 31 percent in 2013. The findings thus suggest that employment after the program recovered faster in eligible industries than in ineligible industries. In fact, the data show that in eligible industries employment levels were back at pre-crisis levels in 2011, while in ineligible industries employment levels were still not back at pre-crisis levels in 2013. The impact estimates are robust to several alternative specifications and a falsification exercise.

\footnotetext{
${ }^{1}$ Based on the ILO/World Bank Inventory of policy responses to the global financial and economic crisis of 2008 (http://www.ilo.org/empelm/projects/WCMS_158875/lang--en/index.htm)
} 
I then use individual level employment data from the Mexican Labor Market Survey (ENOE) to gauge whether the measured effect reflects movements in and out of social security registration instead of reflecting actual increases in employment and do not find this to be the case. ENOE data also show no evidence of displacement effects on employment in ineligible durable goods manufacturing industries.

The measured impact of wage subsidies on firms' employment levels are larger than other estimates in the literature. Kangasharju (2007) show that wage subsidies for hiring unemployed workers in Finland raised employment in eligible firms by $9 \%$ and Betcherman, Daysal, and Pagés (2010) find that employment subsidies to firms that created new jobs in Turkey led to an increase in registered jobs in eligible provinces by up to $15 \%$. In fact, the finding that the effect of wage subsidies was greater after the subsidy period than before is unique in the literature. Most papers measure the effect of wage subsidies during the period when the subsidies are being paid. Two exceptions are Card and Hyslop (2005) for Canada and Groh et al. (2015) for Jordan. Both of these papers find positive short-term impacts on employment, but that these effects dissipate after the subsidy ended.

The findings thus suggest that the use of wage subsidies may be particularly effective during an economic crisis since they can be paid for a relatively short amount of time and still have lasting effects on employment. At the same time, the results raise a question about the channel through which the wage subsidies worked. The intention of the program was to allow firms to keep workers with jobspecific skills, but the estimated effect on employment, while positive, is not statistically significant during the program's duration. Larger, statistically significant effects, only emerge after the program ended. One possible explanation is that the program affected which types of workers subsidized firms kept vs. let go. That is, subsidized firms may have kept the workers with the most specialized and relevant skills in greater proportion than firms in ineligible industries. However, data from the ENOE do not support this argument. Instead, the data suggest that the employees who were laid off during the crisis were predominantly those with the lowest job tenure, who presumably have the lowest levels of job specific skills, both in eligible and ineligible industries.

Another potential explanation is that it was not the firing restrictions that allowed employment to recover faster after the crisis, but rather the subsidy funds. These funds may have provided liquidity for hiring back workers, thereby allowing firms to take advantage of market opportunities at a time when other funding sources were scarce. In fact, firms typically received the subsidy many months after they limited layoffs, and the time when funds started to be paid out corresponds to the time when employment in eligible industries started to increase again after its initial drop during the crisis.

The remainder of this paper is structured as follows: Section 2 describes the wage subsidy program; Section 3 the data and identification strategy; Section 4 the results and robustness checks; and Section 5 concludes. 


\section{Wage subsidy program}

The Mexican government announced the wage subsidy program on January 7, 2009 and it was officially launched on January 30, 2009. The program was operated by the Ministry of Economy (Secretaría de Economía) as Part B of the Program for the Development of High Technology Industries (Programa para el Desarrollo de las Industrias de Alta Tecnología - PRODIAT) and lasted until August 2009. ${ }^{2}$ It provided subsidies to firms in eligible industries who kept employees on their payroll and agreed on reduced work schedules with them instead of firing these employees. Under this arrangement, workers would temporarily receive less salary, but they would keep their job. At the same time, firms had to pay lower salaries and they later received a payment from the government corresponding to a proportion of these salaries (described in more detail below).

To receive a subsidy, firms were not allowed to fire more than one-third of their workforce as a percentage of the drop in sales they had experienced during the economic crisis, e.g. if sales dropped by $30 \%$, they could not fire more than $10 \%$ of their workforce. The program applied to permanent employees who were registered with IMSS. The Ministry of Economy used data from IMSS, together with audited statements of sales, to verify that firms met the restrictions on firing. The operating rules stated that payments would only be made after the necessary information on employees and sales for the subsidy period was available, i.e. after the end of this period. Firms also had to be current on their federal tax and social security payments to be eligible for the subsidies.

Firms applied for the subsidies for one or more two-month periods (e.g. January, February 2009 or February, March 2009). The original operating rules specified that applications had to be submitted by the end of the second month, e.g. February 28, 2009 for the January, February period, and firms had to file written documents with a council specifying the reduced work schedule agreements they had reached with their employees (Secretaría de Gobernación 2009, Annexes E and F). These conditions were relaxed in the modified operating rules from April 10,2009. The new rules stated that firms could submit applications referring to a two-month period at any time during the life of the program and agreements with workers had to made internally, but not filed with a council.

The size of the subsidy corresponded to 110 pesos (US\$6.95) per worker for each day in the applicable two-month period (typically 60 days), multiplied by a) the firm's percentage drop in sales, b) the percentage of workers retained, and c) the number of workers receiving between 1 and 10 minimum wages, or $75 \%$ of the workforce (whichever was greater). ${ }^{3}$ For example, a firm that experienced a $30 \%$ drop in sales, retained $90 \%$ of their workforce, and had 100 eligible workers received $110 \times 60 \times 0.3 \times 0.9$ $x 100=178,200$ pesos. The maximum value of the subsidy that each firm could receive was set at 5,100

\footnotetext{
${ }^{2}$ Part A provides matching grants for up to $70 \%$ of the cost for projects related to technology transfer that address market failures, including training, consulting, licensing, and patents, for any firms or organizations that engage in high technology activities. PRODIAT did not disburse any of these matching grants in 2009 and only disbursed 2 matching grants with a total value of 3.9 million pesos (US\$250,000) in 2010 and 8 matching grants with a total value of 9.8 million pesos (US\$680,000) in 2011.

3 Throughout the paper, I use an exchange rate of 15.82 pesos per US Dollar.
} 
pesos (US\$323) per eligible worker. For comparison, the average daily minimum wage in 2009 was 53 pesos, or US\$3.35 (CONASAMI 2015).

The wage subsidy program received 744 applications, of which 339 are approved, going to 396 plants for preserving 309,206 jobs (Secretaría de Economía 2012). These numbers correspond to $3.8 \%$ of employers and $34 \%$ of permanent employees in eligible industries. ${ }^{4}$ Applications that were not approved did not meet the eligibility requirements and/or firing restrictions of the program.

The total amount of funding disbursed through the program was about 1 billion pesos (US\$63 million), corresponding to about US\$160,000 per plant on average. Comprehensive information on individual subsidies is not available, but partial data from the Ministry of the Economy on 203 beneficiary plants suggests that amounts ranged from 20,670 pesos (US\$1,307) to 50.6 million pesos (US\$3.2 million given to Volkswagen Mexico), with a median of about 1.5 million pesos (US\$92,522). As a reference point for the size of this amount, the average size of a loan or line of credit among manufacturing firms in eligible sectors in the 2010 World Bank Enterprise Survey, which covers a representative sample of firms in Mexico, was about 5.4 million pesos (US\$340,000), conditional on having a loan or line of credit (47\% of firms).

In practice, firms typically received the subsidy many months after they limited layoffs, in part because the process of reviewing applications and disbursing funds took some time. Most funds were approved starting in June 2009 (Galhardi 2009) and some of the amounts were still paid out in later years: out of the total US\$63 million, US\$53 million were disbursed in 2009, US\$1.5 million in 2010 and US\$8.5 million in 2011 (Secretaría de Economía 2012).

\section{Data and identification strategy}

\subsection{Data sources}

Data on employment come from IMSS. The data are at the industry level (as per the IMSS industry classification) and include the total number of employees registered with IMSS in each month from January 2000 to November 2013. I use the data for years 2004 through 2013 to estimate the effects of the wage subsidy program and the data for 2000 to 2003 for a falsification exercise.

I also use monthly data on US imports (total aggregated from world) for the period of January 2004 to December 2013, as a control variable. This data come from the US International Trade Commission's Interactive Tariff and Trade DataWeb and were hand matched to the IMSS industry data using converted Harmonized Tariff Schedule (HTS) codes, at the 4 or 6-digit level, depending on the industry. Due to differences in the industry classifications, not all industries could be matched, so that US import data are missing for a quarter of the IMSS industries in the study sample.

\footnotetext{
${ }^{4}$ Calculations based on data from IMSS for December 2008. IMSS reports number of employers, which may either be plants or firms.
} 


\subsection{Defining the study sample}

According to the Ministry of the Economy, the program targeted industries with four characteristics (Secretaría de Economía 2009). First, they produce durable goods, allowing consumers to postpone purchasing decisions and thus potentially leading to large drops in demand during economic downturns. Second, employees possess a high level of firm or industry specific knowledge, making job loss particularly costly for firms and employees. Third, much of their production is exported either directly or indirectly, exposing them to downturns in other countries. And fourth, they have displayed high levels of growth in the past few years and may thus be able to resume their high growth after the crisis.

In practice, all 29 industries in IMSS classification groups 36 (Manufacture, assembly and/or repair of machinery, equipment and related parts; excluding electronics), 37 (Manufacture and/or assembly of electronic machinery, equipment, appliances, accessories and related parts) and 38 (Constructions, reconstruction and assembly of transportation equipment and parts) were declared eligible for the program. ${ }^{5}$

The empirical challenge for measuring the impact of the program on employment then is to find a set of ineligible industries that are comparable to the eligible industries in the following sense: in the months and years following the program, average employment levels across these industries should follow the same trend as average employment levels across eligible industries would have displayed in absence of the program. Whether or not it is possible to find a credible set of control industries depends on how exact the targeting of the program was. If IMSS industry groups 36,37 , and 38 indeed include all industries with the four characteristics mentioned above, it may not be possible to find a set of industries with similar employment trends. However, some other industry groups may also include subindustries with similar characteristics.

To define a comparable set of eligible and ineligible industries, I use the following procedure. I first keep only IMSS industries that produce durable goods (71 industries in total). For classification of goods as durable or not, I relied on the US Economic Classification Policy Committee aggregation of sectors into groupings called "Supersectors."

Within the set of durable goods industries, I then use propensity score matching (Dehejia and Wahba 2002) based on the following variables: average employment levels in each semester of 2004, 2005, and 2006, average employment levels in each quarter of 2007 and the first two quarters of 2008, and average employment levels each two-month period for July/August, September/October, and November/December of 2008.

\footnotetext{
${ }^{5}$ Some firms producing nondurable goods, such as rubber and plastic, were also declared eligible for the program in the April 10, 2009 revision of the operating rules, under the condition that $90 \%$ of their production is used as an input in other eligible industries.

${ }^{6}$ As posted on the Bureau of Labor Statistics website: http://www.bls.gov/ces/cessuper.htm
} 
I use employment as the matching variable since it is the outcome variable of interest and previous research finds that past values of the outcome of interest are the ones that are most strongly correlated with the future outcome (Bruhn and McKenzie 2009). That is, since the outcome of interest is employment, matching on past employment is likely to yield the most comparable groups of industries in the post-program period. ${ }^{7}$ I use averages over increasingly shorter time periods to better capture the growth path of employment in the past few years before the program and to capture the employment response to the crisis, which started to hit Mexico in the second half of 2008.

After obtaining the propensity score by running a probit regression of an indicator variable for being eligible for the program on the employment variables listed above, I examine three different alternatives for selecting comparable industries a) the common support of the propensity score across eligible and ineligible industries, b) keeping industries with a propensity score that falls between the 20th and $80^{\text {th }}$ percentile of the score, and (c) nearest neighbor caliper matching without replacement using the logit of the propensity score and calipers of width equal to 0.2 of the standard deviations of this variable, as recommended in Austin (2011 and 2014).

Tables 1 and 2 test whether the above methods yield a sample of eligible and ineligible industries that is comparable in terms of employment levels, and, most importantly, in terms of employment trends in the pre-program period (from Jan 2004 to December 2008). If employment trends were the same in the pre-program period, we can assume that they would have continued being the same in the postprogram period in the absence of the program.

The results in tables 1 and 2 show that, in the full sample of durable goods industries, eligible industries had higher employment levels in the pre-program period (this difference is large, 47 percent, but not statistically significant), and they displayed a steeper trend in employment than ineligible industries. These differences remain when considering only industries on the common support of the propensity score and also when keeping only industries with a propensity score between the 20 and $80^{\text {th }}$ percentiles of the score. However, the sample obtained through caliper matching looks more comparable. In this sample of 34 industries, average employment across eligible and ineligible industries differed by 24.5 percent (not statistically significant) and, most importantly, the trends in employment were virtually the same.

Figures 1 through 4 illustrate the comparability of eligible and ineligible industries graphically. Figure 1 plots average employment over time in eligible and ineligible industries for all durable goods industries, and figures 2 through 4 plot average employment for the samples defined using methods a) through c). The vertical lines in each figure show the start and end dates of the wage subsidy program (January through August 2009). In figure 4, which shows the sample obtained through caliper matching, average

\footnotetext{
${ }^{7}$ As described above, the program also intended to reach sectors producing goods for export. However, I do not have accurate data on exports for all IMSS industries producing durable goods since import/export data is recorded under a different industry classification that does not allow for a direct mapping to the IMSS industry classification. The empirical analysis in section 4 includes a specification that controls for imports by Mexico's largest trading partner (the US) using only the industries that could unambiguously be mapped to IMSS industries.
} 
employment behaves very similarly across eligible and ineligible industries - it follows the same trend overall and also displays small seasonal jumps in both sets of industries. Moreover, the drop in employment during the recent crisis, which started in mid-2008, looks similar in the pre-program period across eligible and ineligible industries.

In the remainder of the paper, I thus use the sample of 34 caliper matched industries to measure the effect of the wage subsidy program on employment (appendix table 1 lists these industries and their names).

\section{Results}

\subsection{Estimation equations}

I use the following equation to estimate the effect of the wage subsidy program on employment

$y_{i t}=\propto_{i}+\beta_{t}+\gamma$ Eligible $_{i} *$ DuringProgram $_{t}+$ SEligible $_{i} *$ AfterProgram $_{t}+\varepsilon_{i t}$

where $y_{i t}$ is $\log$ employment in industry $i$ and month $t, \alpha_{i}$ is an industry fixed effect, $\beta_{t}$ is a month fixed effect. The variable Eligible $e_{i}$ is equal to one for all eligible industries and equal to zero for ineligible industries. The variable DuringProgram $m_{t}$ is equal to one for January 2009 through August 2009 and zero for all other months, and the variable AfterProgram $\mathrm{t}_{\mathrm{t}}$ is equal to one for September 2009 through November 2013 and zero for all other months. $\varepsilon_{i t}$ is an error term, clustered at the industry level. Equation 1 thus estimates the effect of the program on employment while the program was in operation and also the effect after the program ended. I also use the following related specification, to estimate the effect of the program for each post-program year separately

$y_{i t}=\propto_{i}+\beta_{t}+\sum_{s=2009}^{2013} I[s=t] \gamma_{s}$ Eligible $_{i} *$ Year $_{s}+\varepsilon_{i t}$

For both equations 1 and 2, I conduct two types of robustness checks. First, I add the fourth root of US imports (from all countries) in industry $i$ and month $t$ as a control variable. ${ }^{8}$ Controlling for US imports addresses the concern that employment in eligible and ineligible industries may evolve differently in the post-program period if demand for Mexican exports in these industries behaved differently. In this case, I would attribute differences in employment to the program, whereas it was actually driven by differences in export demand. I control for US imports since the US is Mexico's largest trading partner. I chose to control for US imports from all countries instead of US imports from Mexico only since the former variable is less likely to be affected by the Mexican wage subsidy program, i.e. it is more likely to be exogenous to the program. As mentioned above, data on US imports is not available for all 34 industries in the sample. Due to mismatches in industry classifications I only have data on US imports for

\footnotetext{
${ }^{8} /$ use the fourth root since it mimics a log function, but does not drop zeros and 2.72 percent of the observations are zeros. Using log of US imports instead gives very similar results.
} 
26 industries. For comparability, I also show the results for estimating equations 1 and 2 without controlling for US imports in the sample of 26 industries for which I have US import data.

The second robustness check excludes the three industries in the sample $(382,388$ and 389) that are directly related to auto manufacturing, along with the three corresponding caliper matched industries (3310, 3510, and 390). The reason for excluding these industries is that both Mexico and the US implemented programs to increase consumer's demand for cars in 2009, which could potentially influence the results. ${ }^{9}$ Similarly, the US also supported General Motors and Chrysler with bailout funding in December 2008 and February 2009. Both of these companies have operations in Mexico and received funds through the wage subsidy program. I thus verify that the findings are not driven by these carindustry specific programs instead, by checking whether the results hold when car industries are excluded from the sample.

\subsection{Effects of the wage subsidy program on employment}

Table 3 shows the results for estimating the effects of the wage subsidy program during its duration and after the program ended. Between January and August 2009, the difference in employment levels across eligible and ineligible industries was not greater than in the pre-program period. The estimated effect of the program is positive, ranging from 5.7 percent to 13.2 percent in magnitude, depending on the specification, but it is not statistically significant in most specifications. However, after the program ended, eligible industries had about 24 percent higher employment than ineligible industries, compared to the pre-program difference in employment. The size of this effect is relatively stable across the different specifications in Table 3.

Table 4 examines the time path of the program's effect in more detail, estimating a separate effect for each year after the program (2009 to 2013). The results show that the effect of the program increases over time - going from about 16 percent in 2010 to 31 percent in 2013. The findings suggest that employment after the program recovered faster in eligible industries than in ineligible industries. Figure 4 shows this difference in employment recovery visually and table 5 provides statistics to illustrate this point further. Compared to the pre-crisis year 2007, employment in 2009 dropped by 11.6 percent in eligible industries and 20.6 percent in ineligible industries. In eligible industries, employment levels started to recover in 2010 and were back at pre-crisis levels in 2011, while in ineligible industries, employment levels were still not back at pre-crisis levels in 2013.

\footnotetext{
${ }^{9}$ The US car buyback program was called the Car Allowance Rebate System. It was originally a 1 billion dollar program slated to run from July 1st to August 25, 2009. However, the program was so successful that the funds were exhausted by June 30th. An additional $\$ 2$ billion was approved, and those funds lasted until August $24^{\text {th }}$. In Mexico, the Programa de Renovacion Vehicular began in August 2009 with a budget of 250 million pesos. It was suspended around March 2010 because of low demand.
} 


\subsection{Are the effects driven by outliers?}

One way of assessing the robustness of the estimates effects is to examine whether they are driven by outliers, i.e. specific industries only. Figure 5 plots the change in the number of employees within an industry, calculated as the log of employees in November 2013, the last month in the data, minus the log of the average number of employees in the pre-2009 period. The figure shows the distribution of these calculated changes, separately for eligible and ineligible industries. One of the ineligible industries (manufacture of asbestos-based products) experienced a particularly large drop in employment of $130 \%$. However, overall the distribution of employment changes in eligible industries lies to the right of the distribution of employment changes in ineligible industries, suggesting that the positive effect of the program on employment was not concentrated in a few industries only. A Kolmogorov-Smirnov test of equality of distributions rejects equality with a $p$-value of 0.017 ( 0.025 if manufacture of asbestos-based products is excluded from the group of ineligible industries). Also, there are no outliers in terms of increases in the number of employees for eligible industries.

I test to see how the estimated program effects would change when weakening the influence of the negative outlier (manufacture of asbestos-based products) by winsorizing this outlier. For all months from January 2009 on, I replace the log number of employees in this industry with the log average pre2009 value plus the drop in employees for the industry that experienced the second largest drop in employment in that month, calculated as log employment in that month minus average log employment over the pre-2009 period. Columns 5 in table 3 and table 4 shows the results in the winsorized data. The estimated effects are somewhat smaller in magnitude, but they are still statistically significant.

\subsection{Falsification exercise}

Although the analysis uses eligible and ineligible industries that displayed the same employment trends in the pre-program period, a potential concern is that employment across these industries would have behaved differently in the post-program period even in the absence of the wage subsidy program. For example, the concern may be that the industries show similar employment trends in good economic times, but respond differently to downturns. I conduct the following falsification exercise to address this concern. I estimate equations 3 and 4 for the time period January 2000 to December 2004, which coincided with a recession in Mexico (from the second quarter of 2001 to the first quarter of 2002),

$y_{i t}=\propto_{i}+b_{t}+\gamma$ Eligible $_{i} *$ RecessionAndAfter $_{t}+\varepsilon_{i t}$

$y_{i t}=\propto_{i}+b_{t}+\sum_{s=2001}^{2003} I[s=t] \gamma_{s}$ Eligible $_{i} *$ Year $_{s}+\varepsilon_{i t}$

where the variables are defined as in equations 1 and 2 and RecessionAndAfter $r_{t}$ is equal to one for April 2001 through December 2003 and zero for all other months.

The results in table 6 show that employment in eligible and ineligible industries did not recover differently after the 2001 recession. This finding lends support to the assumption that eligible and 
ineligible industries would have evolved similarly after the 2008/2009 economic crisis in the absence of the wage subsidy program.

\subsection{Actual employment vs. formal employment}

Since the data on employment comes from the Mexican Social Security Institute (IMSS), I ask the question whether the measured effects reflect changes in actual employment vs. formal employment. For example, it may be the case that firms deregister employees with IMSS after the crisis, without actually laying them off. Then, eligible firms may have re-registered employees during the recovery whereas ineligible firms may have kept employees being informal, i.e. not registered with IMSS.

A related study by Betcherman, Daysal, and Pagés (2010) that uses data on employment from the Social Security Administration in Turkey concludes that the effect of wage subsidies was to increase registration rather than boosting total employment. In the setting here, where subsidies are linked to keeping existing employees, not to hiring new employees, the distinction between formal employment and actual employment may be less relevant. It is presumably more difficult for firms to deregister employees that were previously registered than to register employees who were not previously registered. IMSS registration comes with benefits for the employee, such as medical care, which employees may be reluctant to give up. However, in a crisis situation employees may prefer relinquishing these benefits over losing their job.

I use data from the Labor Market Survey (ENOE) conducted by the Mexican Statistical Institute (INEGI), for the years 2005 through 2014, to examine whether registration rates with IMSS changed with the economic crisis. The ENOE is a quarterly survey that covers about 120,000 households. Unfortunately, the ENOE variable indicating industry of employment is quite broad. It is based on two digit codes from the North American Industry Classification System (NAICS), plus two more digits specific to the ENOE. There are nine industry codes that correspond to durable goods manufacturing. Appendix Table 2 lists these nine codes along with their names and shows how I classified them into eligible vs. ineligible for the wage subsidy program.

The mapping to IMSS industry codes, on which eligibility for the program was based, is not always straightforward. For example, code 3340 in the ENOE includes manufacture of computers, communication and measurement equipment, as well as other electronic equipment. While most of these activities correspond to eligible industries in IMSS industry groups 36 and 37, IMSS classifies measurement equipment in an industry group that was not eligible for the wage subsidy program (group 39). That is, due to mismatches between the ENOE and IMSS classifications, some workers classified as eligible in the ENOE data may in fact not be eligible. ${ }^{10}$

\footnotetext{
${ }^{10}$ In general, I tried to classify the ENOE industry codes as eligible (or ineligible) as accurately as possible based on whether the majority of industries listed in the name were eligible or not under the IMSS classification. For the example given above, this method seems to work relatively well. Data on employment in NAICS industries is available from the Monthly Manufacturing Industry Survey (EMIM) conducted by INEGI. This data shows seven subindustries in code 334 (which has the same name as ENOE industry 3340), one of which is manufacture of
} 
Another caveat with the ENOE industry classification is that the codes are so broad that I cannot separate out only 34 IMSS industries that I use to estimate the effect of the wage subsidy program. Instead, I have to use employees in all durable goods industries. Despite these shortcomings, I believe that the evidence from the ENOE data can shed further light on the impact estimates I obtained with IMSS data.

The ENOE asks individuals whether their job provides them with access to medical services through IMSS or other government institutions vs. no access to such services. Figure 6 plots the number of individuals working in eligible industries who state they have access to IMSS, and separately the number of individuals who state they have no access to government medical care, in each quarter from 2005 to 2014. ${ }^{11}$ On average across these quarters, the ENOE includes about 4,000 individuals who work in eligible industries and have access to IMSS, and only about 130 individuals who work in eligible industries and have no access to government medical care. The number of individuals with access to IMSS drops during the crisis, hitting a low in 2009, and increases steadily thereafter. In contrast, the number of individuals without access to government medical care remains constant throughout all quarters. This constant pattern suggests that the wage subsidy program did not simply shift workers from informal to formal employment and that the impact estimates in this paper reflect changes in actual employment instead.

\subsection{Displacement effects}

There is evidence that labor market programs can have displacement effects, i.e. the program may shift employment from ineligible to eligible jobs instead of creating more jobs overall (Crépon et al. 2013). That is, employment in the control group may be negatively affected by the program and impact estimates may thus overstate its true effect. In the context here, displacement effects are probably not a great concern during the program and in the first years after the program since the subsidy was paid for maintaining existing jobs instead of creating new jobs. In addition, the crisis resulted in layoffs in both eligible and ineligible industries, so that firms in eligible industries had a pool of unemployed workers with previous experience in eligible industries they could draw on when they started to hire back workers in 2009 and 2010. However, once employment in eligible industries reached pre-crisis levels (in 2011), it becomes conceptually more likely that new hires may have come from workers in ineligible industries.

I try to assess whether the wage subsidy program had displacement effects using the data from the ENOE, described in section 4.4. The ENOE has a panel nature and aims to follow each household for five consecutive quarters. I first examine whether eligible industries tend to hire away individuals from

measurement equipment (industry code 334519). In 2009, manufacture of measurement equipment made up only 4.6 percent of the total number of employees in code 334 .

${ }^{11}$ Less than 1 percent of individuals say they have access to medical care through government institutions other than IMSS or that they don't know whether they have access to such care. 
ineligible industries. For individuals who work in an eligible industry in any given quarter, but did not work in an eligible industry in the previous quarter, figure 7 plots how many individuals were in each of the following three categories (i) working in an ineligible durable goods manufacturing industry with access to IMSS, (ii) working in any other industry - nondurable goods manufacturing or outside manufacturing, or (iii) not employed - including the unemployed and individuals out of the labor force. An average of about 840 people start to work in an eligible industry each quarter and about 130 of them worked in an eligible industry and had access to IMSS during the previous quarter, a number that is quite stable over time. I thus do not see evidence that eligible industries are increasingly hiring employees away from ineligible industries after the wage subsidy program.

I also examine whether eligible industries are increasingly hiring individuals who were laid off in ineligible industries. In select quarters, the ENOE included an amplified questionnaire that asks individuals if they lost their job in the past year, extending the panel information about any given individual beyond five quarters. For individuals who report having lost a job with access to IMSS in an ineligible industry during the past year, figure 8 plots the percentage of individuals working in an eligible industry where they have access to IMSS, for the quarter where the amplified questionnaire was applied and for up to four quarters following this quarter. The initial quarter includes only 21 individuals who report having lost their job with access to IMSS in an ineligible industry during the past year, on average, and the number of individuals drops each consecutive quarter due to the rotating panel nature of the ENOE, containing only 4 individuals on average four quarters later. Although based on very few individuals, figure 8 suggests that less than 10 percent of individuals who lose their job with access to IMSS in an ineligible industry get hired in an eligible industry in subsequent quarters and that this small percentage does not increase in quarters after the wage subsidy program. ${ }^{12}$ The patterns in the ENOE data thus do not suggest that the wage subsidy program had displacement effects on ineligible industries.

\subsection{Through which channel did the wage subsidies increase employment?}

As a final exercise, I use ENOE data to shed light on the channel through which the wage subsidies increased employment. The intention of the program was to allow firms to keep workers with jobspecific skills, thus eliminating search and training costs during the recovery. However, the estimated effect on employment, while positive, is not statistically significant during the program's duration. Larger and statistically significant effects only emerge after the program ended. One possible explanation is that although the program did not limit layoffs during the crisis, it affected which types of workers firms kept vs. let go. The program may have allowed firms to keep the workers with the most specialized and relevant skills in greater proportion than firms in ineligible industries.

\footnotetext{
${ }^{12}$ On average, four quarters following the quarter when they report having lost their job with access to IMSS in an ineligible industry, most individuals work in an industry outside durable goods manufacturing (47 percent), remain unemployed (29 percent), or work in an ineligible industry again (16 percent). Only 8 percent work in an eligible industry.
} 
I use job tenure as a measure of job specific skills, i.e. I assume that individuals who have been at their job for longer have greater job specific skills. The ENOE collects information on job tenure through the amplified questionnaire. Unfortunately, this questionnaire is only available once a year for most years and for 2009 it was applied in the first quarter, when the wage subsidy program was recently launched. Figure 9a plots the number of individuals working in eligible industry in a job with access to IMSS, separately for those with two or less years of job tenure and those with more than two years of tenure. Figure $9 \mathrm{~b}$ displays the corresponding numbers for ineligible industries. Both figures show that the number of employees with high job tenure remained stable from 2008 to 2009. In fact, the drop in employment during the crisis seems to be entirely driven by individuals with low job tenure, who presumably have the lowest levels of job specific skills, both in eligible and ineligible industries. That is, even in industries that were not eligible for the wage subsidy program firms decided to lay off employees with the lowest job tenure, thereby preserving job specific skills. ${ }^{13}$

Evidence from the ENOE data does thus not support the hypothesis that the wage subsidy program caused firms to keep employees with job specific skills to a greater extent than they would have in the absence of the program. This evidence needs to be interpreted with caution due to the issues with matching ENOE data to eligible and ineligible IMSS industries, as mentioned above, and also due to the fact that tenure data only exists for the first quarter of the program. However, it does suggest that the program may have worked through a different channel than preserving job-specific skills.

Another potential explanation for the effects measured in this paper is that it was not the firing restrictions that allowed employment to recover faster after the crisis, but rather the payment of the subsidy funds itself. These funds may have provided liquidity for hiring back workers, thereby allowing firms to take advantage of market opportunities at a time when other funding sources were scarce. In fact, the time when employment started to increase again in eligible industries (mid-2009, as shown in figure 4) coincided with the time when the subsidy funds started to be paid out.

In fact, the lack of a statistically significant effect of the wage subsidy program on employment during the duration of the program suggests that the firing restrictions imposed by the program were not binding. That is, firms who received the subsidy would not have fired more than one third of their workforce as a percentage of the drop in sales they experienced during the crisis, even in the absence of the program. It is possible that the program would have had a positive effect on employment during its duration if the firing restrictions had been more stringent. However, another design issue is that since the subsidy was typically paid many months after firms were supposed to limit layoffs, ex-ante firms may have faced uncertainty as to whether they would really receive the funds. That is, some firms who ended up laying off more workers than specified by the program may not have changed their behavior due to a lack of certainty about the program.

\footnotetext{
${ }^{13}$ Another reason of laying off employees with low job tenure is that government mandated severance payments increase with number of years on the job.
} 


\section{Conclusion}

Rising unemployment during an economic crisis is a concern for policy makers and 22 countries around the world used some form of wage subsidy program to promote employment retention during the recent economic crisis. However, empirical evidence on the effects of such programs is scarce. This paper measures the effect of a wage subsidy program in Mexican on employment in manufacturing firms during and after the recent economic crisis, using monthly administrative data along with propensity score matching and a difference-in-difference strategy.

I find a positive, but not statistically significant effect of the wage subsidies on employment during the program's duration, ranging from 5.7 percent to 13.2 percent in magnitude, depending on the specification. The size of the effect increases to 24 percent after the program ended and the results indicate that employment after the program recovered faster in eligible industries than in ineligible industries. In fact, the data show that in eligible industries employment levels were back at pre-crisis levels in 2011, while in ineligible industries employment levels were still not back at pre-crisis levels in 2013.

The findings thus suggest that the Mexican wage subsidy program was an effective tool for tackling unemployment in the wake of an economic crisis. However, this paper does not find evidence that the wage subsidies helped to preserve job specific skills, which was part of the economic rationale for the program. Instead, the positive effect on employment seems to have come from the payment of the subsidy funds itself. 


\section{References}

Austin Peter C. 2011. "Optimal Caliper Widths for Propensity-Score Matching When Estimating Differences in Means and Differences in Proportions in Observational Studies." Pharmaceutical Statistics 10: $150-161$.

Austin Peter C. 2014. "A Comparison of 12 Algorithms for Matching on the Propensity Score." Statistics in Medicine 33 (6): 1057-1069.

Betcherman, Gordon, N. Meltem Daysal, and Carmen Pagés. 2010. "Do employment subsidies work? Evidence from regionally targeted subsidies in Turkey." Labour Economics 17: 710-222.

Betcherman, Gordon, Karina Olivas, and Amit Dar. 2004. "Impacts of Active Labor Market Programs: New Evidence from Evaluations with Particular Attention to Developing and Transition Countries." World Bank Social Protection Discussion Paper no. 402.

Bruhn, M., and D. McKenzie. 2009. "In Pursuit of Balance: Randomization in Practice in Development Field Experiments." American Economic Journal: Applied Economics 1 (4): 200-232.

Card, David, and Dean R. Hyslop. 2005. "Estimating the Effects of a Time-Limited Earnings Subsidy for Welfare-Leavers." Econometrica 73 (6): 1723-1770.

Comisión Nacional de los Salarios Mínimos (CONASAMI). 2015. Salario Mínimo General Promedio de los Estados Unidos Mexicanos 1964-2015. http://www.conasami.gob.mx/t sal gral prom.html

Crépon, Bruno, Esther Duflo, Marc Gurgand, Roland Rathelot and Philippe Zamora. 2013. "Do labor market policies have displacement effect? Evidence from a cluster randomized experiment." Quarterly Journal of Economics 128(2): 531-580.

Dehejia, R., and S.Wahba. 2002. "Propensity Score Matching Methods for Nonexperimental Causal Studies." Review of Economics and Statistics 84 (1): 151-161.

Galhardi, Regina. 2009. "México - Programa para la Perservación del Empleo." Oficina Internacional del Trabajo - Notas sobre la Crisis. Organización Internacional del Trabajo.

Girma, Sourafel, Holger Görg, Eric Strobl, and Frank Walsh, Frank. 2008. "Creating jobs through public subsidies: An empirical analysis." Labour Economics 15(6): 1179-1199.

Groh, Matthew, Nandini Krishnan, David McKenzie and Tara Vishwanath. 2015. “Do Wage Subsidies Provide a Stepping Stone to Employment for Recent College Graduates? Evidence from a Randomized Experiment in Jordan." Review of Economics and Statistics, forthcoming.

Kaldor, Nicholas. 1936. "Wage subsidies as a remedy for unemployment." Journal of Political Economy 44(6): 721-42. 
Kangasharju, Aki. 2007. “Do Wage Subsidies Increase Employment in Subsidized Firms?” Economica 74 (293): 51-67.

Katz, Lawrence. 1998. "Wage subsidies for the disadvantaged", in Richard Freeman and Peter Gottschalk (eds.) Generating Jobs: How to Increase Demand for Less-skilled workers. Russell Sage Foundation: New York, NY.

Layard, P.R.G. and S.J. Nickell. 1980. "The case for subsidizing extra Jobs." Economic Journal 90(357): 5173.

Phelps, Edmund S. 1994. "Low-Wage Employment Subsidies versus the Welfare State." American Economic Review 84 (2): 54-58.

Secretaría de Economía. 2009. "Programa para la Preservación del Empleo." Mimeo.

Secretaría de Economía. 2012. "Programa para el Desarrollo de las Industrias de Alta Tecnología PRODIAT: Evaluación de Consistencia y Resultados 2011-2012. Anexos."

http://www.economia.gob.mx/conoce-la-se/programas-se/informes-de-evaluacionesexternas/prodiat\#!prettyPhoto

Secretaría de Gobernación. 2009. Reglas de Operación del Programa para el Desarrollo de las Industrias de Alta Tecnología (PRODIAT). Actualizadas al 30 de Enero de 2009. 
Figure 1: Average employment over time in all durable goods industries

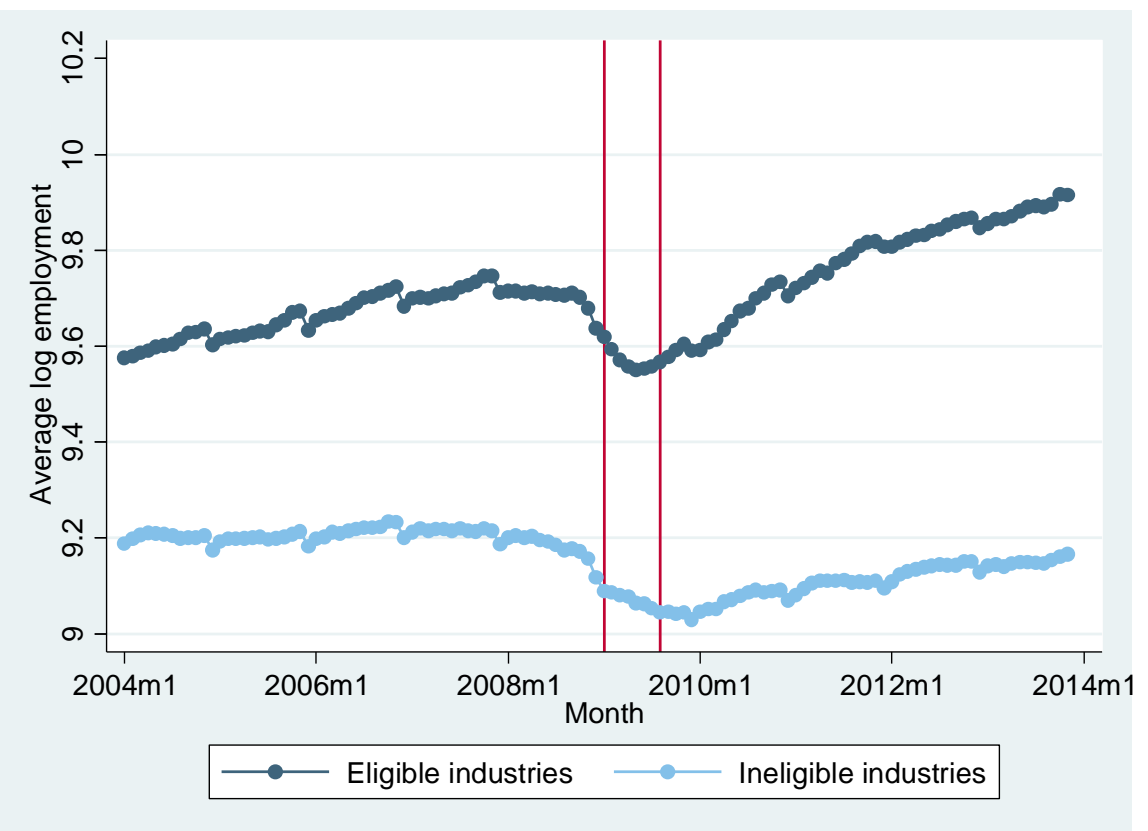

Note: The figure displays data from the Mexican Social Security Institute (IMSS). The two vertical lines denote the start and end of the wage subsidy program (January and August 2009).

Figure 2: Average employment over time in matched industries (common support)

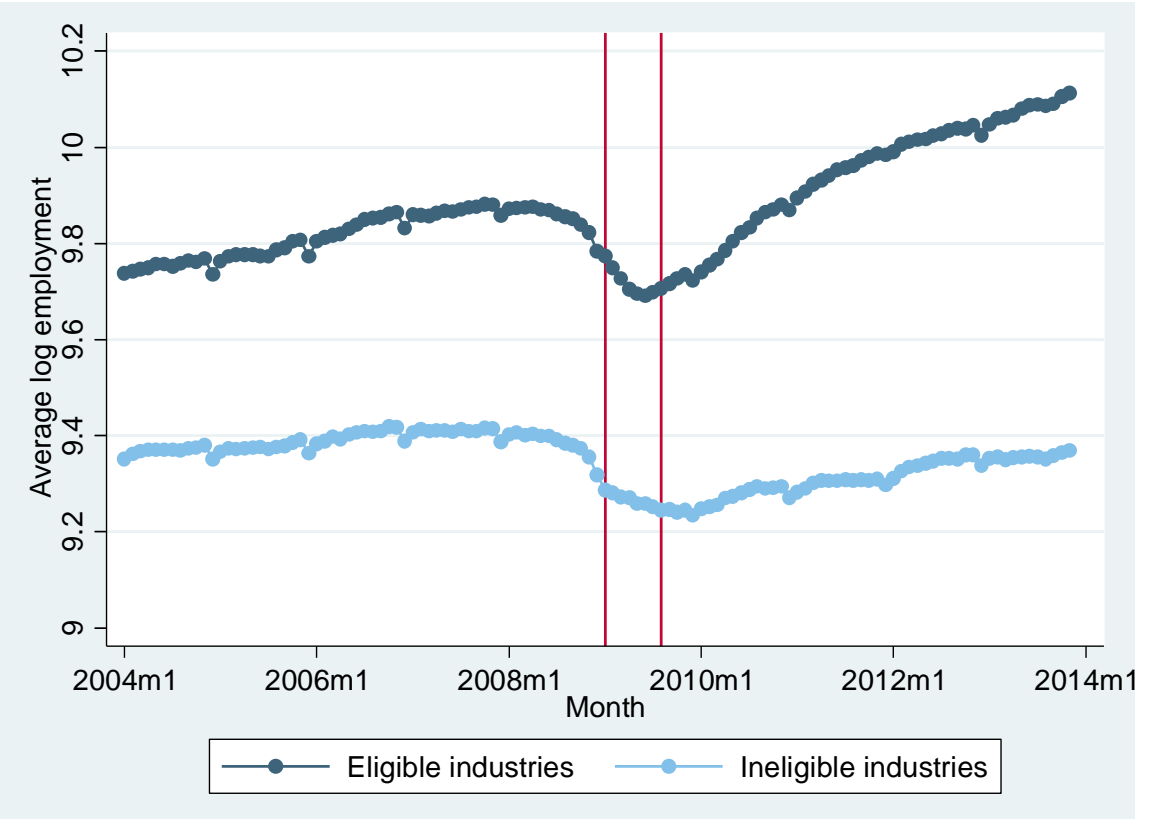

Note: The figure displays data from the Mexican Social Security Institute (IMSS). The two vertical lines denote the start and end of the wage subsidy program (January and August 2009). 
Figure 3: Average employment over time in matched industries (pscore $>=20$ th and $<=80$ th pctile)

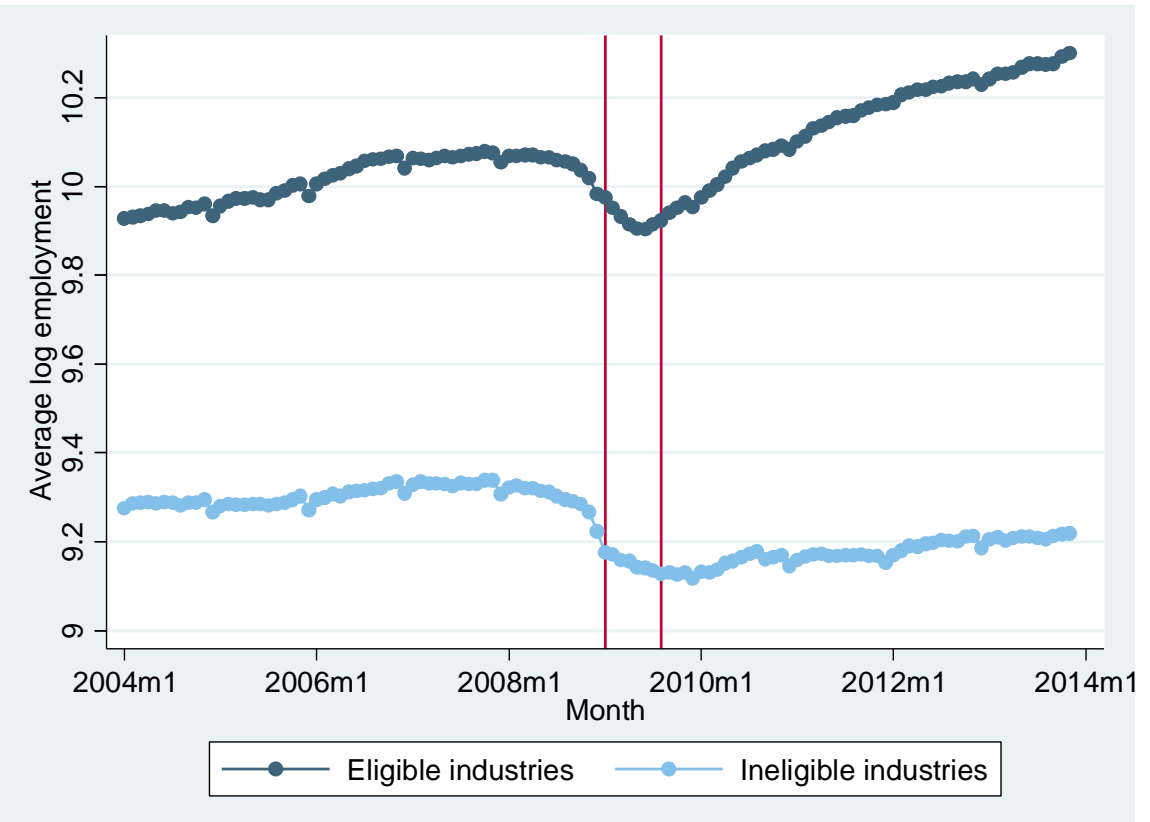

Note: The figure displays data from the Mexican Social Security Institute (IMSS). The two vertical lines denote the start and end of the wage subsidy program (January and August 2009).

Figure 4: Average employment over time in matched industries (caliper)

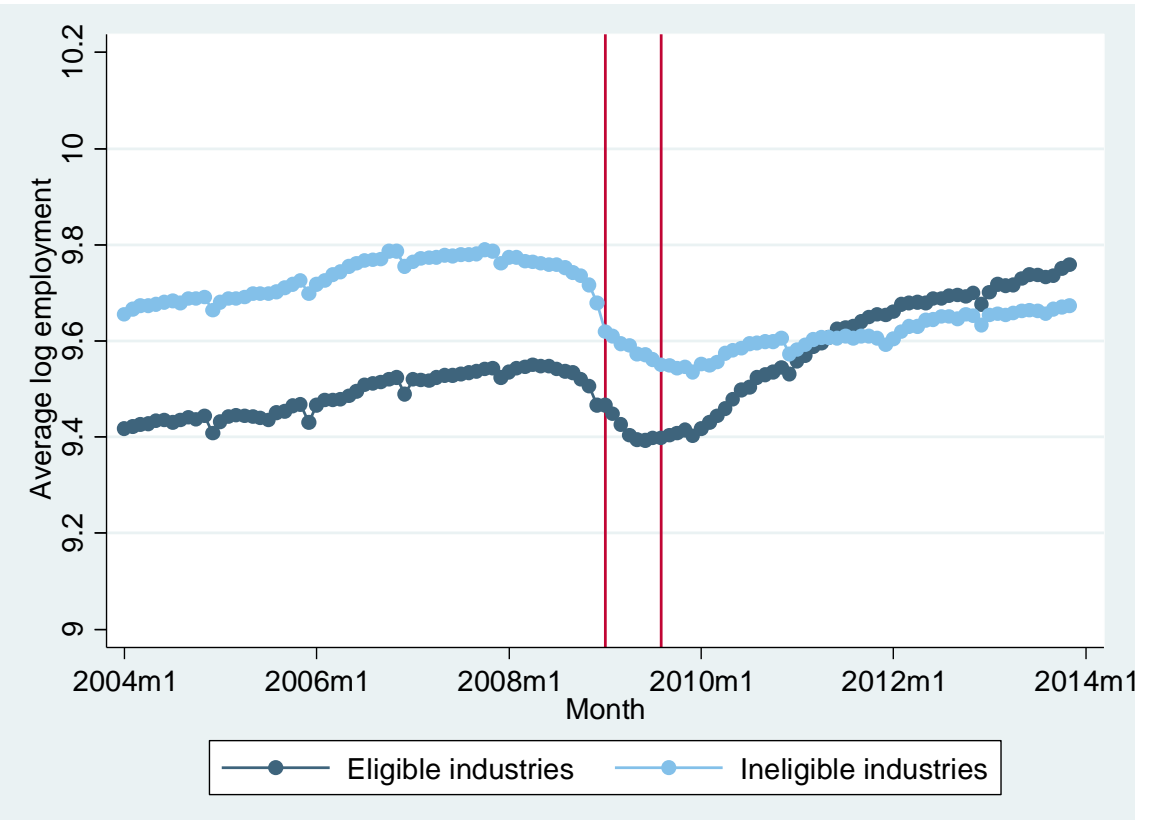

Note: The figure displays data from the Mexican Social Security Institute (IMSS). The two vertical lines denote the start and end of the wage subsidy program (January and August 2009). 
Figure 5: Distribution of employment changes in eligible and ineligible industries

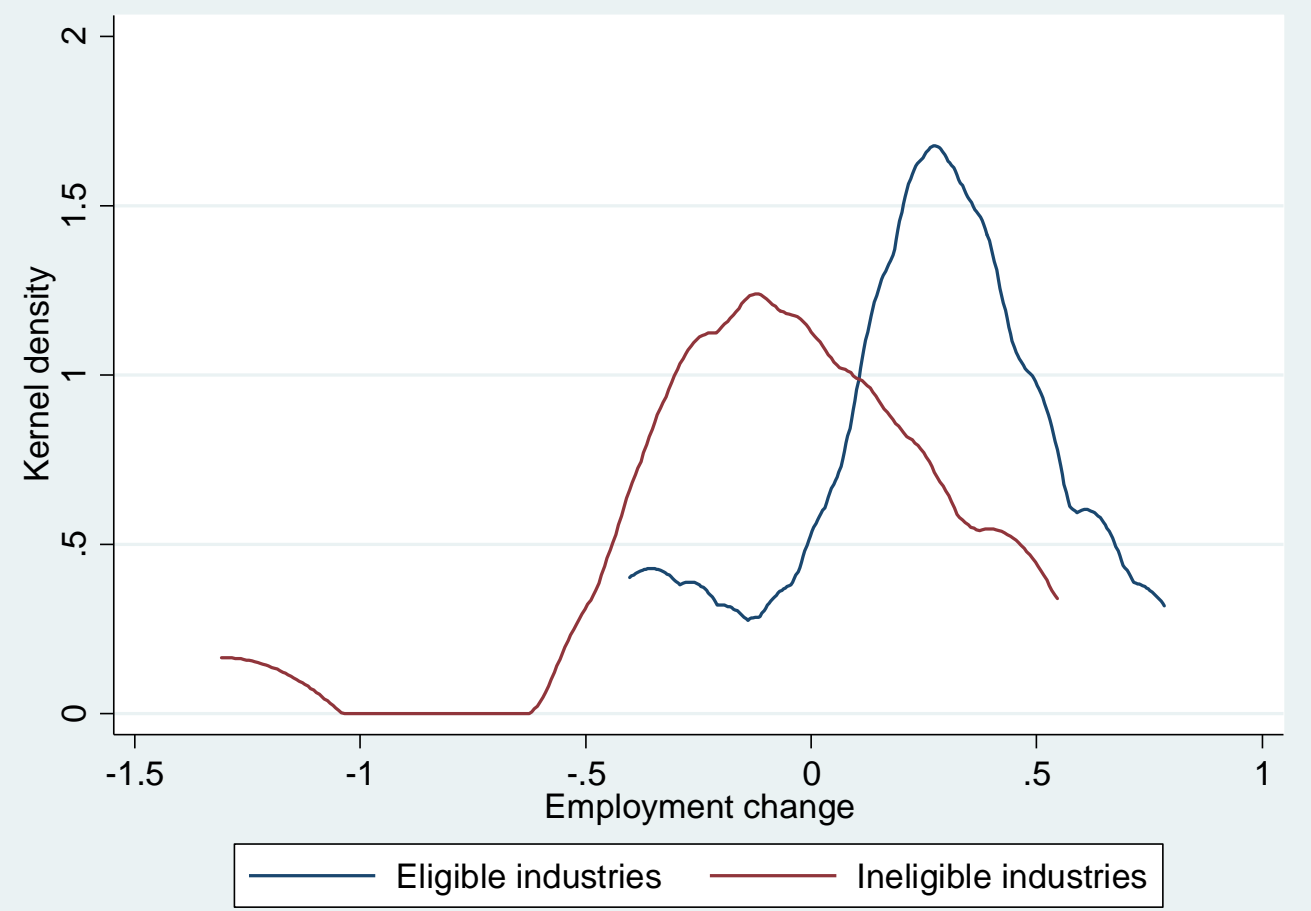

Note: The figure displays the distribution of employment changes in eligible and ineligible industries.

Employment change is calculated as the log of employees in November 2013, the last month in the IMSS data, minus the log of the average number of employees in the pre-2009 period. 
Figure 6: Formal vs. informal employment in eligible industries

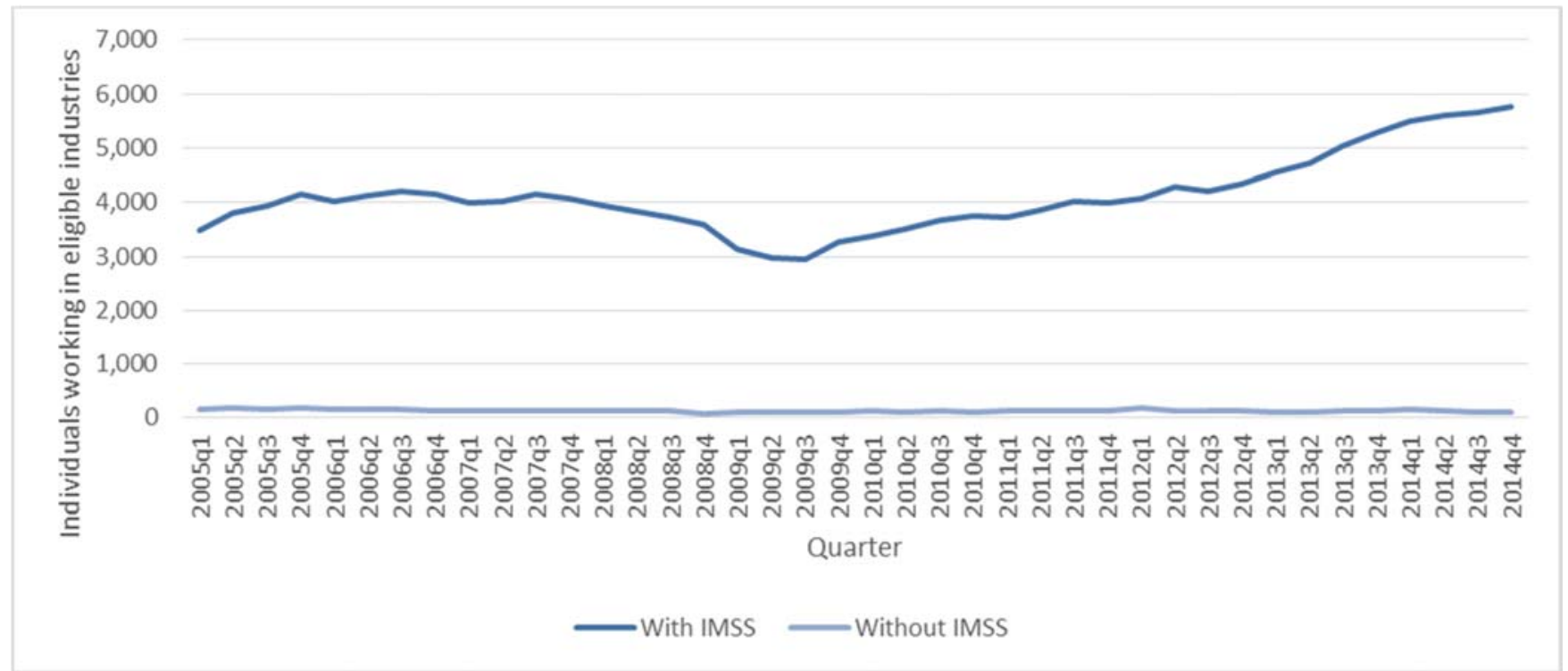

Note: The figure displays data from the Mexican Labor Market Survey (ENOE). It plots the number of individuals working in industries eligible for the wage subsidy program who report having access to medical services through IMSS and the number of individuals working in eligible industries who report not having access to such services. 
Figure 7: Individuals transitioning into eligible industries by previous employment category

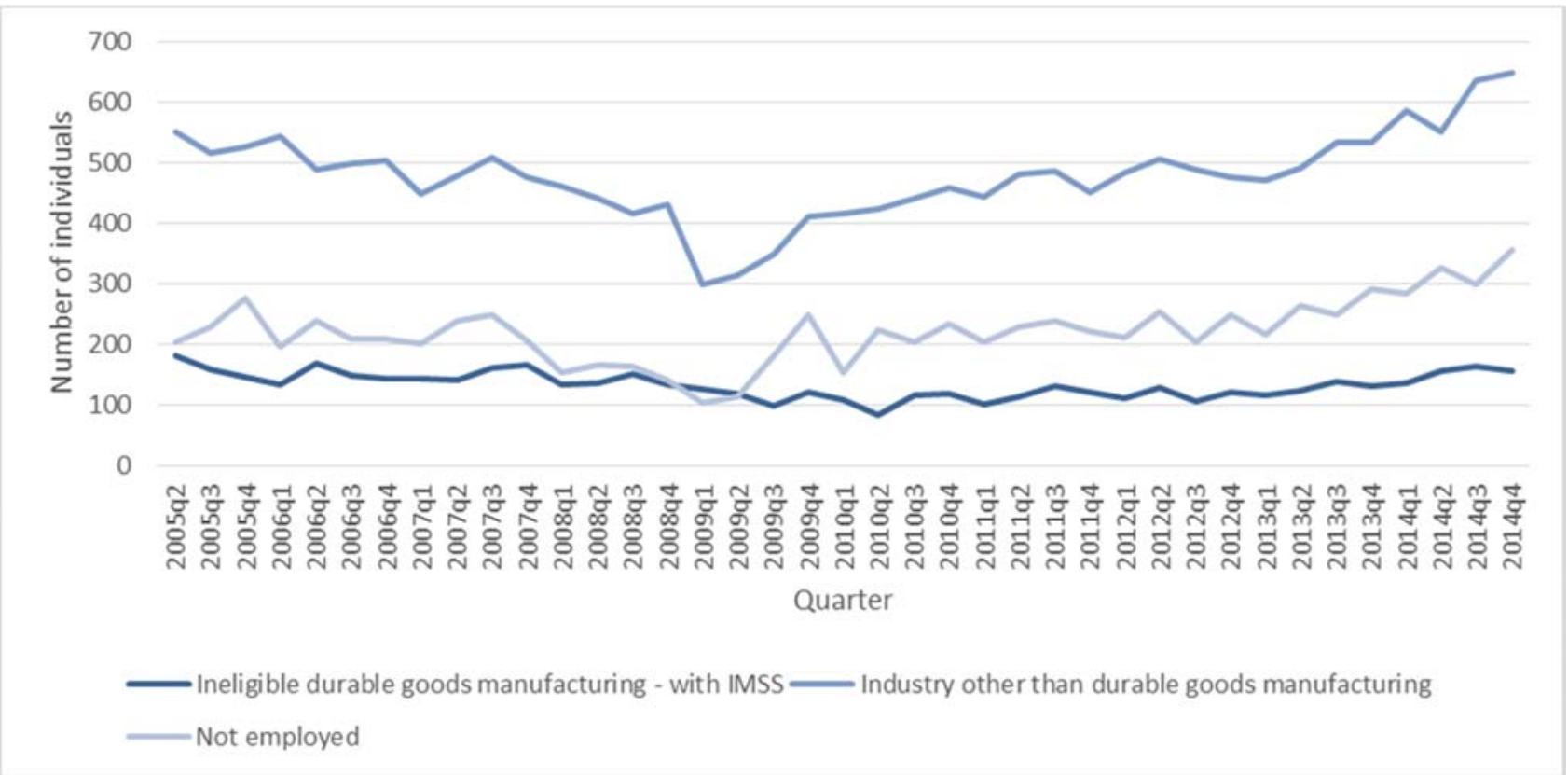

Note: The figure displays data from the Mexican Labor Market Survey (ENOE). It plots the number of individuals who work in industries eligible for the wage subsidy program in the current quarter and have access to IMSS, but did not work in an eligible industry in the previous quarter, broken up by their employment category in the previous quarter. 
Figure 8: Percentage of individuals who lost their job in an ineligible industry and who later work in an eligible industry

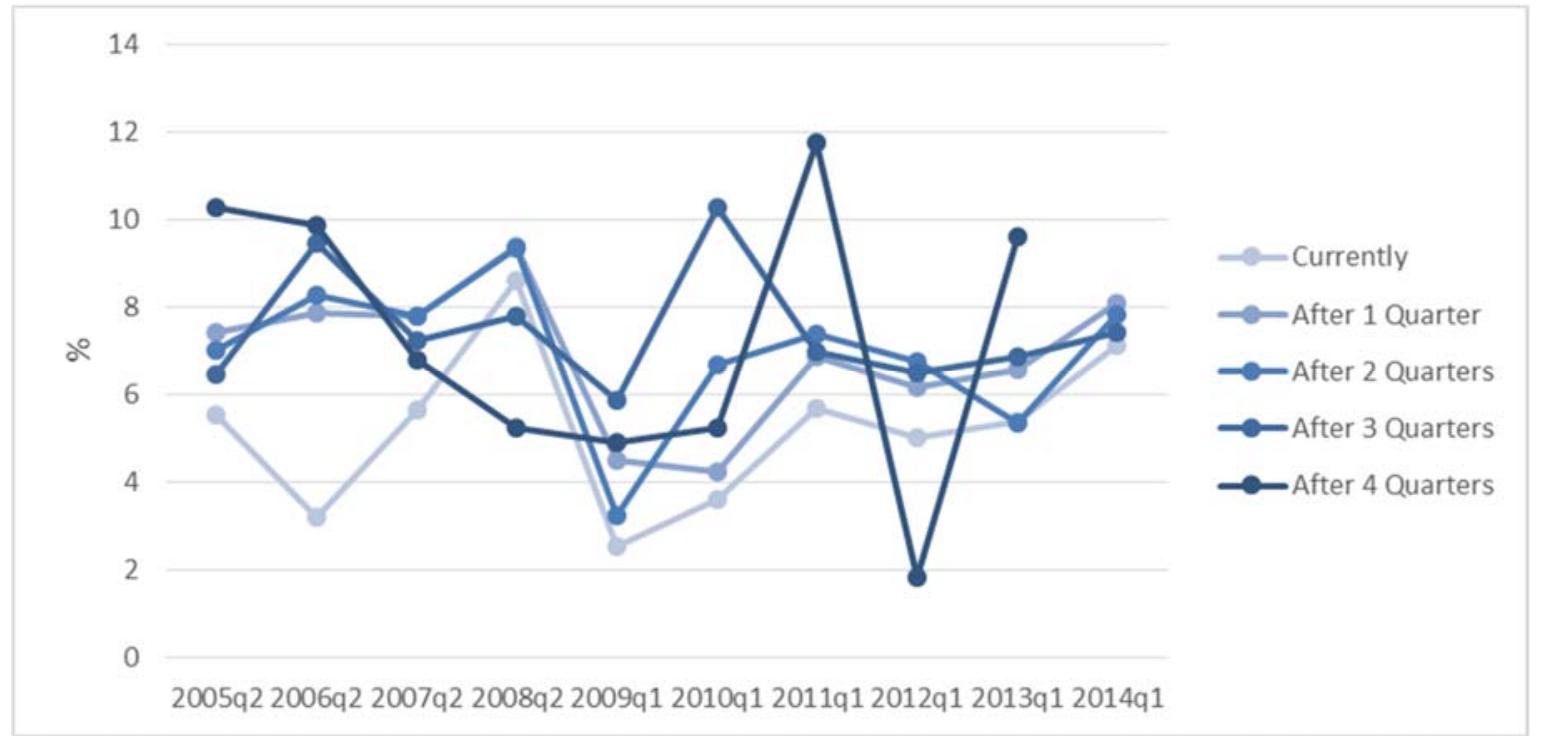

Note: The figure displays data from the Mexican Labor Market Survey (ENOE), from an amplified questionnaire that was applied in select quarters and that asks individuals if they lost their job in the past year. For individuals who report having lost a job with access to IMSS in an ineligible industry during the past year, the figure plots the percentage of individuals working in a job with access to IMSS in an eligible industry for the quarter where the amplified questionnaire was applied, as well as for the four quarters following this quarter. 
Figure 9: Number of Individuals working in durable goods manufacturing industries by job tenure

a. Eligible industries

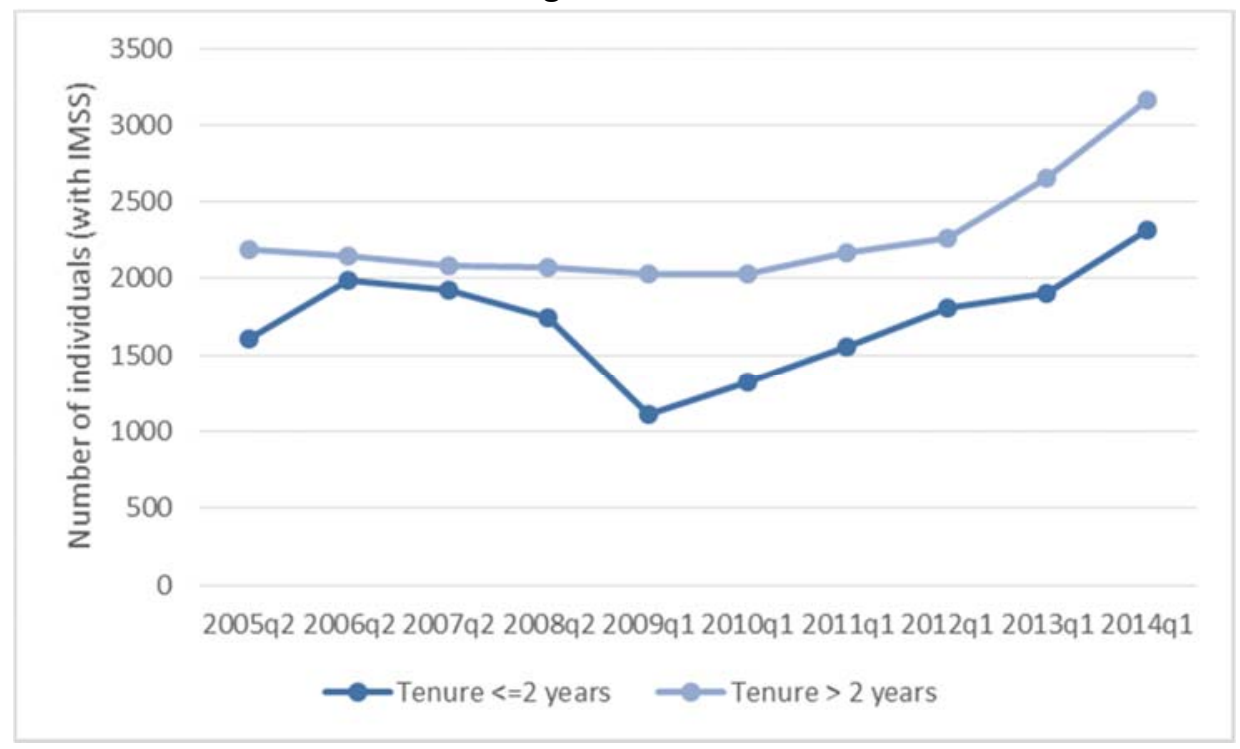

b. Ineligible Industries

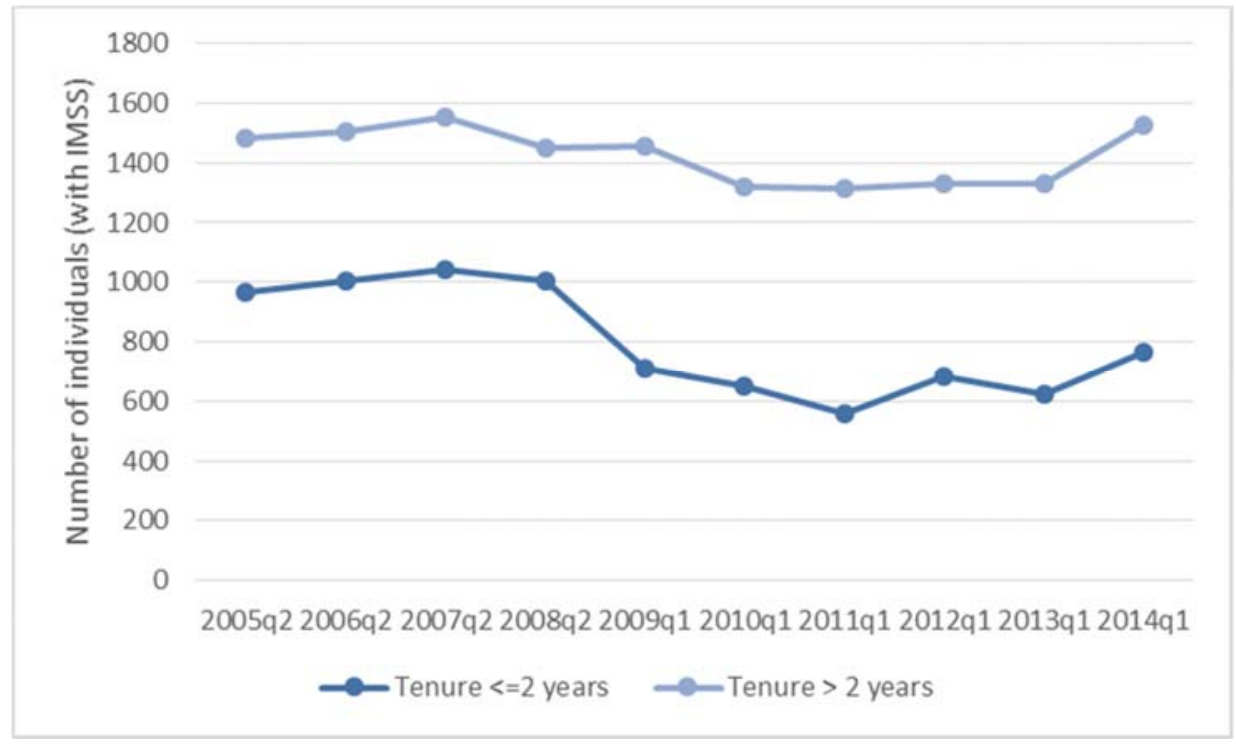

Note: The figure displays data from the Mexican Labor Market Survey (ENOE), from an amplified questionnaire that was applied in select quarters. It shows the number or individuals working in eligible and ineligible industries who report having access to IMSS, broken down by whether they have been at their job for two years or less or for more than two years. 
Table 1: Pre-Program Employment Averages (2004 - 2008)

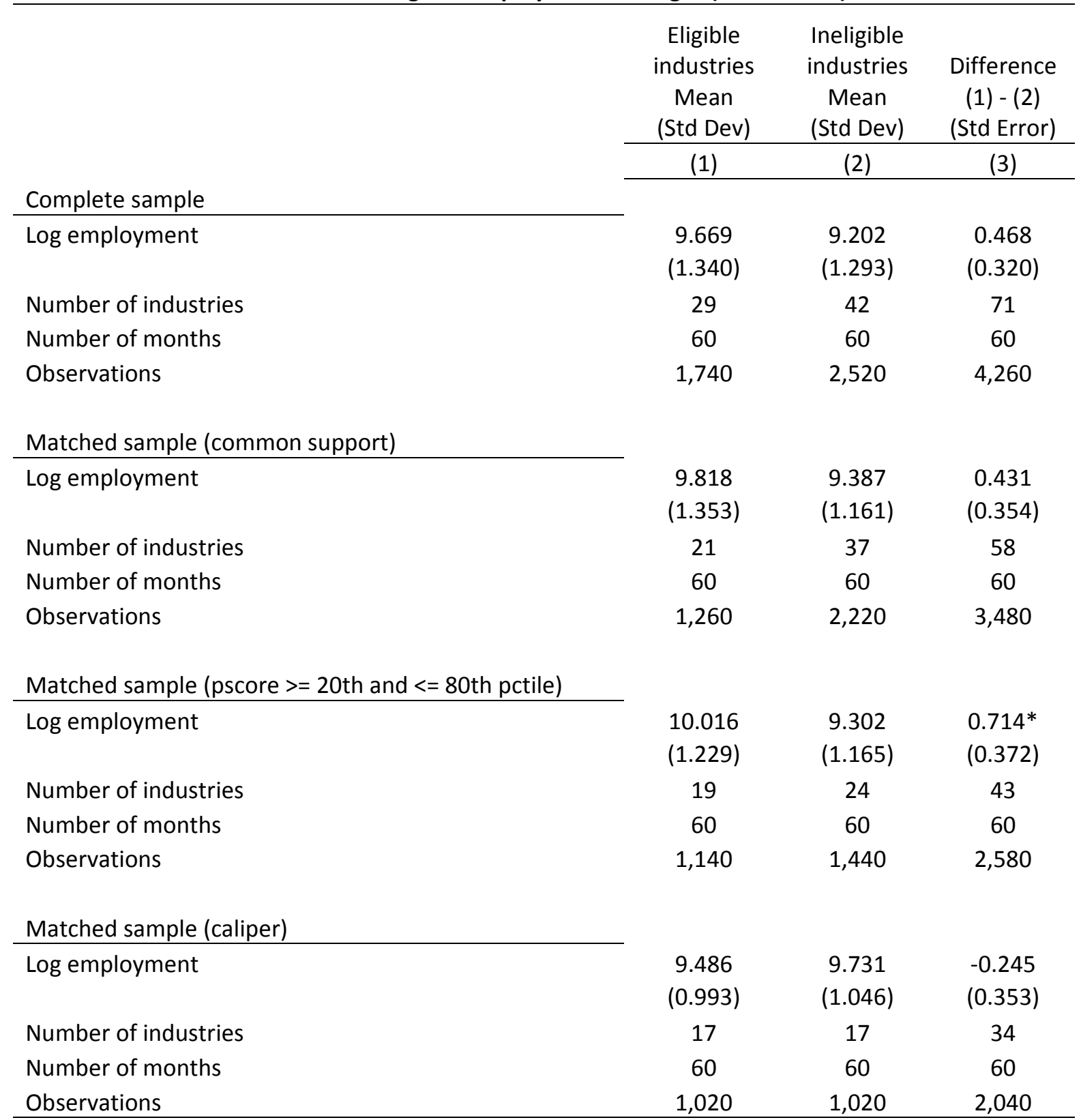

Notes: Data covers all months from January 2004 to December 2008. Column 3 reports coefficients from regressing log employment on an indicator variable that is equal to one for all eligible industries and equal to zero for ineligible industries. Robust standard errors in parentheses, clustered at the industry level. $*, * *$, and ${ }^{* * *}$ indicate significance at the 10,5 and 1 percent levels respectively. 


\begin{tabular}{|c|c|c|c|}
\hline & $\begin{array}{c}\text { Eligible } \\
\text { industries } \\
\text { Coefficient } \\
\text { on linear } \\
\text { time trend } \\
\text { (Std Error) }\end{array}$ & $\begin{array}{l}\text { Ineligible } \\
\text { industries } \\
\text { Coefficient } \\
\text { on linear } \\
\text { time trend } \\
\text { (Std Error) }\end{array}$ & $\begin{array}{c}\text { Difference } \\
\text { (1) - (2) } \\
\text { (Std Error) }\end{array}$ \\
\hline & (1) & (2) & (3) \\
\hline \multicolumn{4}{|l|}{ Complete sample } \\
\hline Log employment & $\begin{array}{c}0.023^{* *} \\
(0.010)\end{array}$ & $\begin{array}{l}-0.002 \\
(0.007)\end{array}$ & $\begin{array}{c}0.026^{* *} \\
(0.012)\end{array}$ \\
\hline Number of industries & 29 & 42 & 71 \\
\hline Number of months & 60 & 60 & 60 \\
\hline Observations & 1,740 & 2,520 & 4,260 \\
\hline \multicolumn{4}{|c|}{ Matched sample (common support) } \\
\hline Log employment & $\begin{array}{c}0.024^{* *} \\
(0.010)\end{array}$ & $\begin{array}{c}0.005 \\
(0.006)\end{array}$ & $\begin{array}{c}0.018 \\
(0.012)\end{array}$ \\
\hline Number of industries & 21 & 37 & 58 \\
\hline Number of months & 60 & 60 & 60 \\
\hline Observations & 1,260 & 2,220 & 3,480 \\
\hline \multicolumn{4}{|c|}{ Matched sample (pscore $>=20$ th and $<=80$ th pctile) } \\
\hline Log employment & $\begin{array}{c}0.025^{* *} \\
(0.010)\end{array}$ & $\begin{array}{c}0.005 \\
(0.006)\end{array}$ & $\begin{array}{l}0.020^{*} \\
(0.011)\end{array}$ \\
\hline Number of industries & 19 & 24 & 43 \\
\hline Number of months & 60 & 60 & 60 \\
\hline Observations & 1,140 & 1,440 & 2,580 \\
\hline \multicolumn{4}{|c|}{ Matched sample (caliper) } \\
\hline Log employment & $\begin{array}{l}0.023^{*} \\
(0.012)\end{array}$ & $\begin{array}{c}0.018^{* *} \\
(0.008)\end{array}$ & $\begin{array}{c}0.005 \\
(0.015)\end{array}$ \\
\hline Number of industries & 17 & 17 & 34 \\
\hline Number of months & 60 & 60 & 56 \\
\hline Observations & 1,020 & 1,020 & 1,920 \\
\hline
\end{tabular}

Notes: Data covers all months from January 2004 to December 2008. Column 3 reports the coefficient on the interaction term when regressing log employment on an indicator variable that is equal to one for all eligible industries and equal to zero for ineligible industries, a linear time trend, and the interaction of the time trend with the indicator variable. Robust standard errors in parentheses, clustered at the industry level. ${ }^{*}, * *$, and ${ }^{* * *}$ indicate significance at the 10,5 and 1 percent levels respectively. 
Table 3: Effect of the Wage-Subsidy Program on Employment

\begin{tabular}{|c|c|c|c|c|c|}
\hline & & Dependen & fariable: Lo & employment & \\
\hline & (1) & $(2)$ & (3) & (4) & (5) \\
\hline During program dummy: & 0.078 & 0.113 & $0.132 *$ & 0.109 & 0.057 \\
\hline Eligible*(Jan 2009 - Aug 2009) & $(0.067)$ & $(0.075)$ & $(0.075)$ & $(0.077)$ & $(0.056)$ \\
\hline After program dummy: & $0.243 * *$ & $0.321^{* * *}$ & $0.329 * * *$ & $0.278^{* *}$ & $0.210 * *$ \\
\hline Eligible*(Post Aug 2009) & $(0.102)$ & $(0.114)$ & $(0.111)$ & $(0.115)$ & $(0.085)$ \\
\hline US imports^(1/4) & & & 0.016 & & \\
\hline & & & $(0.013)$ & & \\
\hline R-squared & 0.977 & 0.975 & 0.976 & 0.974 & 0.982 \\
\hline Number of industries & 34 & 26 & 26 & 28 & 34 \\
\hline Number of months & 119 & 119 & 119 & 119 & 119 \\
\hline Observations & 4,046 & 3,094 & 3,094 & 3,332 & 4,046 \\
\hline Sample & All & Only wit & $\begin{array}{l}\text { US import } \\
\text { ta }\end{array}$ & $\begin{array}{l}\text { Without car } \\
\text { manufacturing } \\
\text { and closest } \\
\text { matches }\end{array}$ & $\begin{array}{c}\text { All, } \\
\text { winsorized } \\
\text { outlier }\end{array}$ \\
\hline $\begin{array}{l}\text { Notes: Data covers all months } f \\
\text { January } 2009 \text { on, employment } \\
\text { experienced a particularly large } \\
2009 \text { value plus the drop in em } \\
\text { employment in that month (cal } \\
\text { over the pre- } 2009 \text { period). Rob } \\
* * * \text { indicate significance at the }\end{array}$ & $\begin{array}{l}\text { nuary } 200 \\
\text { neligible i } \\
\text { n employ } \\
\text { s for the i } \\
\text { as log er } \\
\text { hdard err } \\
\text { nd } 1 \text { perc }\end{array}$ & $\begin{array}{l}\text { lovember } \\
\text { "manuf } \\
\text { during the } \\
y \text { that exp } \\
\text { nent in th } \\
\text { oarenthes } \\
\text { vels respe }\end{array}$ & $\begin{array}{l}\text { 13. In colu } \\
\text { ure of asb } \\
\text { isis, is repl } \\
\text { ienced the } \\
\text { month min } \\
\text { clustered } \\
\text { vely. }\end{array}$ & $\begin{array}{l}\text { 5, for all montt } \\
\text { os-based produ } \\
\text { d with the log a } \\
\text { cond largest dro } \\
\text { average log em }\end{array}$ & $\begin{array}{l}\text { from } \\
\text { ", which } \\
\text { erage pre- } \\
\text { in } \\
\text { loyment } \\
* * * \text { and }\end{array}$ \\
\hline
\end{tabular}


Table 4: Effect of the Wage-Subsidy Program on Employment by Year

\begin{tabular}{|c|c|c|c|c|c|}
\hline & \multicolumn{5}{|c|}{ Dependent variable: Log employment } \\
\hline & (1) & $(2)$ & $(3)$ & $(4)$ & (5) \\
\hline \multirow[t]{2}{*}{ Eligible*2009 } & 0.088 & 0.116 & 0.132 & 0.119 & 0.074 \\
\hline & $(0.072)$ & $(0.079)$ & $(0.078)$ & $(0.084)$ & $(0.064)$ \\
\hline \multirow[t]{2}{*}{ Eligible*2010 } & $0.157^{*}$ & $0.191^{*}$ & $0.203^{* *}$ & $0.196 *$ & 0.146 \\
\hline & $(0.092)$ & $(0.098)$ & $(0.095)$ & $(0.105)$ & $(0.086)$ \\
\hline \multirow[t]{2}{*}{ Eligible*2011 } & $0.259 * *$ & $0.332 * * *$ & $0.340 * * *$ & $0.296 * *$ & $0.230 * *$ \\
\hline & $(0.099)$ & $(0.110)$ & $(0.107)$ & $(0.111)$ & $(0.085)$ \\
\hline \multirow[t]{2}{*}{ Eligible*2012 } & $0.291^{* *}$ & $0.404 * * *$ & $0.407 * * *$ & $0.325 * *$ & $0.242 * *$ \\
\hline & $(0.116)$ & $(0.132)$ & $(0.130)$ & $(0.131)$ & $(0.093)$ \\
\hline \multirow[t]{2}{*}{ Eligible*2013 } & $0.314 * *$ & $0.434 * * *$ & $0.438 * * *$ & $0.347 * *$ & $0.263^{* *}$ \\
\hline & $(0.127)$ & $(0.147)$ & $(0.143)$ & $(0.144)$ & $(0.103)$ \\
\hline \multirow[t]{2}{*}{ US imports^(1/4) } & \multicolumn{5}{|c|}{0.015} \\
\hline & \multicolumn{5}{|c|}{$(0.013)$} \\
\hline R-squared & 0.981 & 0.976 & 0.977 & 0.975 & 0.982 \\
\hline Number of industries & 34 & 26 & 26 & 28 & 34 \\
\hline Number of months & 119 & 119 & 119 & 119 & 119 \\
\hline Observations & 4,046 & 3,094 & 3,094 & 3,332 & 4,046 \\
\hline $\begin{array}{l}\text { F-test } p \text {-value: equality of effects } \\
\text { over time }\end{array}$ & 0.006 & 0.002 & 0.0076 & 0.002 & 0.007 \\
\hline Sample & All & $\begin{array}{r}\text { Only with } \\
\text { da }\end{array}$ & $\begin{array}{l}\text { JS import } \\
\text { ta }\end{array}$ & $\begin{array}{l}\text { Without car } \\
\text { manufacturing } \\
\text { and closest } \\
\text { matches }\end{array}$ & $\begin{array}{c}\text { All, } \\
\text { winsorized } \\
\text { outlier }\end{array}$ \\
\hline \multicolumn{6}{|c|}{$\begin{array}{l}\text { Notes: Data covers all months from January } 2004 \text { to November } 2013 \text {. In column } 5 \text {, for all months from } \\
\text { January } 2009 \text { on, employment in the ineligible industry "manufacture of asbestos-based product", which } \\
\text { experienced a particularly large drop in employment during the crisis, is replaced with the log average pre- } \\
2009 \text { value plus the drop in employees for the industry that experienced the second largest drop in } \\
\text { employment in that month (calculated as log employment in that month minus average log employment } \\
\text { over the pre-2009 period). Robust standard errors in parentheses, clustered at the industry level. *, } * * \text {, and } \\
* * * \text { indicate significance at the } 10,5 \text { and } 1 \text { percent levels respectively. }\end{array}$} \\
\hline
\end{tabular}


Table 5: Post-Program Recovery in Average Employment Levels

\begin{tabular}{|c|c|c|c|c|c|c|c|}
\hline & 2007 & 2008 & 2009 & 2010 & 2011 & 2012 & 2013 \\
\hline & $(1)$ & $(2)$ & $(3)$ & $(4)$ & $(5)$ & $(6)$ & $(7)$ \\
\hline \multicolumn{8}{|l|}{ Eligible industries } \\
\hline Avg. log employment & 9.529 & 9.531 & 9.413 & 9.491 & 9.616 & 9.684 & 9.730 \\
\hline - Difference to 2007 & & 0.002 & -0.116 & -0.038 & 0.088 & 0.155 & 0.201 \\
\hline \multicolumn{8}{|l|}{ Ineligible industries } \\
\hline Avg. log employment & 9.776 & 9.748 & 9.570 & 9.580 & 9.602 & 9.638 & 9.661 \\
\hline - Difference to 2007 & & -0.028 & -0.206 & -0.196 & -0.174 & -0.138 & -0.115 \\
\hline
\end{tabular}

Table 6: Falsification Exercise

\begin{tabular}{|c|c|c|}
\hline & \multicolumn{2}{|c|}{$\begin{array}{c}\text { Dependent variable: } \\
\text { Log employment }\end{array}$} \\
\hline & $(1)$ & $(2)$ \\
\hline Recession and after dummy: & -0.049 & \\
\hline Eligible*(Post Mar 2001) & $(0.039)$ & \\
\hline \multirow[t]{2}{*}{ Eligible*2001 } & & -0.026 \\
\hline & & $(0.027)$ \\
\hline \multirow[t]{2}{*}{ Eligible*2002 } & & -0.063 \\
\hline & & $(0.044)$ \\
\hline \multirow[t]{2}{*}{ Eligible*2003 } & & -0.052 \\
\hline & & $(0.051)$ \\
\hline R-squared & 0.995 & 0.995 \\
\hline Number of industries & 34 & 34 \\
\hline Number of months & 48 & 48 \\
\hline Observations & 1,632 & 1,632 \\
\hline \multicolumn{3}{|c|}{ Notes: Data covers all months from January 2000 to December 2003.} \\
\hline \multicolumn{3}{|c|}{$\begin{array}{l}\text { Robust standard errors in parentheses, clustered at the industry level. *, } \\
* * \text {, and } * * * \text { indicate significance at the } 10,5 \text { and } 1 \text { percent levels } \\
\text { respectively. }\end{array}$} \\
\hline
\end{tabular}


Appendix Table 1: List of Caliper Matched Industries Used to Estimate the Effect of the Wage Subsidy Program

\begin{tabular}{|c|c|c|}
\hline $\begin{array}{l}\text { IMSS } \\
\text { code }\end{array}$ & Eligible & Name \\
\hline 264 & 0 & Manufacture of cork, palm, cane, reed and wicker products \\
\hline 271 & 0 & Manufacture or repair of wooden furniture and related parts \\
\hline 332 & 0 & Manufacturing of toilets, china, porcelain and refractory items \\
\hline 335 & 0 & Manufacture of clay products for construction \\
\hline 337 & 0 & Manufacture of asbestos-based products \\
\hline 339 & 0 & Manufacture of artificial granite, marble and other stone products \\
\hline 342 & 0 & Manufacture of primary products made of iron, steel and nonferrous metals using automated processes \\
\hline 352 & 0 & Manufacture or repair of doors, windows, metal curtains and other products from iron \\
\hline 355 & 0 & Manufacture of metal cans, bottle caps and lids \\
\hline 356 & 0 & Manufacture of wires and other wire products \\
\hline 390 & 0 & $\begin{array}{l}\text { Manufacture, assembly and/or repair of scientific and professional equipment and measuring and control } \\
\text { instruments }\end{array}$ \\
\hline 392 & 0 & Manufacturing, installation and/or assembly of watches, jewelry and gold work \\
\hline 399 & 0 & $\begin{array}{l}\text { Manufacture, assembly and/or repair of other manufactured goods without machinery or motorized equipment not } \\
\text { previously classified }\end{array}$ \\
\hline 3310 & 0 & Manufacture of concrete products and pre-built parts \\
\hline 3313 & 0 & Manufacture of glass and products made of glass with automated processes \\
\hline 3510 & 0 & Other fabricated metal products manufacturing \\
\hline 3910 & 0 & $\begin{array}{l}\text { Manufacture, assembly and/or repair of other manufactured goods with machinery or motorized equipment not } \\
\text { previously classified }\end{array}$ \\
\hline 362 & 1 & $\begin{array}{l}\text { Manufacture and/or assembly of machinery, equipment and supplies for the production of food, beverages, tobacco, } \\
\text { textiles, footwear, wood, leather, printing, rubber, plastic products, } \\
\text { nonmetallic minerals (except cement) and metalworking }\end{array}$ \\
\hline 363 & 1 & $\begin{array}{l}\text { Manufacture and assembly of machinery, equipment or tools used in construction, extraction, paper, cement, } \\
\text { chemical and primary petrochemical industries; primary iron, steel and nonferrous metals }\end{array}$ \\
\hline 364 & 1 & Manufacture and assembly of office machinery, computers, sewing machines and related parts \\
\hline 365 & 1 & Repair and assembly of sewing machines and office machinery \\
\hline 366 & 1 & Manufacture of parts and spare parts for machinery and equipment in general \\
\hline 367 & 1 & Repair and/or maintenance of general machinery and equipment \\
\hline 371 & 1 & $\begin{array}{l}\text { Manufacture and/or assembly of machinery and equipment for the generation and transformation of electrical } \\
\text { energy }\end{array}$ \\
\hline 374 & 1 & Manufacture and/or assembly of electronics, consumer appliances and related parts \\
\hline 376 & 1 & Manufacture and/or assembly of batteries (dry), electronic components and various electronics \\
\hline 377 & 1 & Manufacture and/or assembly of lamps (bulbs) and vacuum tubes for electric lighting \\
\hline 382 & 1 & Manufacture and/or assembly of bodywork for vehicles \\
\hline 386 & 1 & Manufacturing, assembly and/or repair of railcars, railway equipment and related parts \\
\hline 388 & 1 & Manufacture and/or assembly of automobiles, buses, trucks and motorcycles \\
\hline 389 & 1 & Manufacture and/or assembly of engines for cars, buses and trucks \\
\hline 3710 & 1 & Manufacture of lamps and neon signs \\
\hline 3711 & 1 & Manufacture of electric accumulators in mass production or with continuous processes \\
\hline 3712 & 1 & Manufacturing and/or assembly of refrigerators, stoves, washing machines, dryers and other major appliances \\
\hline
\end{tabular}


Appendix Table 2: List of Durable Manufacturing Industries in ENOE

\begin{tabular}{lll}
\hline $\begin{array}{l}\text { ENOE } \\
\text { code }\end{array}$ & Eligible & Name \\
\hline 3330 & 1 & Manufacture of machinery and equipment \\
3340 & 1 & Manufacture of computers, communication, measurement, and other electronic equipment, components and accessories \\
3350 & 1 & Electrical equipment, appliance, and component manufacturing \\
3360 & 1 & Manufacture of transportation equipment and automobile parts \\
3210 & 0 & Wood product manufacturing \\
3270 & 0 & Non-metallic mineral product manufacturing \\
3310 & 0 & Primary metal manufacturing \\
3320 & 0 & Metal product manufacturing \\
3370 & 0 & Manufacture of furniture, mattresses and blinds \\
\hline
\end{tabular}

